\title{
EFFECT OF VISUAL ATTENTION ON CONTRALATERAL SUPPRESSION OF ACOUSTIC REFLEXES
}

\author{
Prashanth Prabhu, Akriti Kumar, Raveendran Revathi, Shezeen Abdul Gafoor
}

Department of Audiology, All India Institute of Speech and Hearing, Manasagangothri, Mysore, India

Corresponding author: Prashanth Prabhu, Department of Audiology, All India Institute of Speech and Hearing, Manasagangothri, Naimisham Campus, Mysore, Karnataka, India - 570006, Tel: +91-8904353390, e-mail: prashanth.audio@gmail.com

\begin{abstract}
Background: Cortical functions such as attention can affect the functioning of the medial efferent auditory system. This study attempts to determine the effect of visual attention on contralateral suppression of acoustic reflexes.

Material and methods: Contralateral suppression of acoustic reflex threshold (CSART) and contralateral suppression of acoustic reflex amplitude (CSARA) were determined in 30 normal hearing individuals at 500, 1000, and $2000 \mathrm{~Hz}$. CSART and CSARA were determined for four visual attention tasks: no attention, passive attention, and two active visual attention tasks.

Results: Contralateral suppression of acoustic reflexes was enhanced in the active visual attention condition compared to the no visual attention condition. No significant difference was observed across gender in any of the conditions.

Conclusions: Visual attention tasks can have a direct effect on the medial auditory efferent system and hence needs to be monitored. To enhance suppression a well-controlled active visual attention task should be used.
\end{abstract}

Key Words: visual attention $\bullet$ acoustic reflex threshold $\bullet$ acoustic reflex amplitude $\bullet$ suppression $\bullet$ efferent auditory system

\section{EFECTO DE LA CONCENTRACIÓN VISUAL EN LA SUPRESIÓN DE LOS REFLEJOS ESTAPEDIALES EN EL OIDO OPUESTO}

\section{Resumen}

Introducción: Las funciones corticales como la concentración afectan al funcionamiento del sistema central eferente. El objetivo de este estudio es determinar la influencia de la concentración visual en la supresión de los reflejos estapediales en el oído opuesto.

Material y métodos: En 30 pacientes con umbrales de audición normales se evaluó la supresión de umbrales de reflejos estapediales en el oído opuesto (CSAR) y la supresión de las amplitudes de reflejos estapediales en el oído opuesto (CSARA) para la frecuencia de 500, 1000 y $2000 \mathrm{~Hz}$. También se realizó el estudio CSART y CSARA para cuatro estados en términos de la concentración visual: falta de concentración, concentración pasiva y dos tareas en la concentración visual activa.

Resultados: La supresión de los reflejos estapediales en el oído opuesto fue reforzado en condiciones de la concentración visual activa. No se observaron diferencias relevantes en cuanto al sexo en ninguno de los casos examinados.

Conclusiones: La concentración visual puede tener un efecto directo sobre el sistema auditivo central eferente y por lo tanto debe ser monitoreada. Para fortalecer la supresión son necesarias tareas bien controladas en el campo de la concentración visual.

Palabras clave: concentración visual • umbral de los efectos estapedial • amplitud de los reflejos estapediales • supresión • sistema auditivo eferente. 


\title{
ВЛИЯНИЕ ЗРИТЕЛЬНОГО ВНИМАНИЯ НА ПОДАВЛЕНИЕ СТАПЕДИАЛЬНЫХ РЕФЛЕКСОВ В ПРОТИВОПОЛОЖНОМ УХЕ
}

\author{
Изложение \\ Введение: Корковые функции, такие как внимание, влияют на центральную слуховую эфферентную систему. \\ Целью настоящего исследования является определение влияния зрительного внимания на подавление стапе- \\ диальных рефлексов в противоположном ухе. \\ Материал и методы: У 30 человек с нормальным слухом оценено подавление порогов стапедиальных рефлек- \\ сов в противоположном ухе (CSART) и подавление амплитуд стапедиальных рефлексов в противоположном \\ yxe (CSARA) для частот 500, 1000 и 2000 Гц. Произведено также исследование CSART и CSARA для четырех со- \\ стояний в области зрительного внимания: отсутствие внимания, пассивное внимание и два задания при ак- \\ тивном зрительном внимании.
}

Результаты: Подавление стапедиальных рефлексов в противоположном ухе усилилось в условиях активного зрительного внимания. Значительных разниц по поводу пола ни в одном из исследуемых случаев не наблюдалось.

Итоги: Зрительное внимание может иметь непосредственное влияние на центральную слуховую эфферентную систему, и поэтому ее тоже надо мониторировать.

Ключевые слова: зрительное внимание • порог стапедиальных рефлексов • амплитуда стапедиальных рефлексов • подавление • слуховая эфферентная система

\section{WPŁYW KONCENTRACJI WZROKOWEJ NA TŁUMNIENIE ODRÓCHÓW STRZEMIĄCZKOWYCH W UCHU PRZECIWNYM}

\section{Streszczenie}

Wprowadzenie: Funkcje korowe takie jak koncentracja wpływają na funkcjonowanie ośrodkowego systemu słuchowego eferentnego. Celem tego badania jest określenie wpływu koncentracji wzrokowej na tłumienie odruchów strzemiączkowych w uchu przeciwnym.

Materiał i metody: U 30 osób z normalnym słuchem oceniono tłumienie progów odruchów strzemiączkowych w uchu przeciwnym (CSART) oraz tłumienie amplitud odruchów strzemiączkowych w uchu przeciwnym (CSARA) dla częstotliwości 500, 1000 i 2000 Hz. Wykonano także badanie CSART i CSARA dla czterech stanów w zakresie koncentracji wzrokowej: brak koncentracji, koncentracja pasywna oraz dwa zadania przy aktywnej koncentracji wzrokowej.

Wyniki: Tłumienie odruchów strzemiączkowych w uchu przeciwnym było wzmocnione w warunkach aktywnej koncentracji wzrokowej. Nie zaobserwowano istotnych różnic odnośnie płci w żadnym z badanych przypadków.

Wnioski: Koncentracja wzrokowa może mieć bezpośredni wpływ na ośrodkowy system słuchowy eferentny i dlatego też powinna być monitorowana. Aby wzmocnić tłumienie potrzebne są dobrze kontrolowane zadania w zakresie koncentracji wzrokowej.

Słowa kluczowe: koncentracja wzrokowa • próg odruchów strzemiączkowych • amplituda odruchów strzemiączkowych • tłumienie • system słuchowy eferentny

\section{Background}

The efferent auditory system plays a vital part in human auditory perception. The medial olivocochlear bundle has a major role in perception of speech in the presence of noise [1,2], protection of the inner ear against loud sounds [3,4], and localization of sounds [5]. The medial efferent system also plays an important role in auditory attention [6,7]. During a focused attention task, the medial olivocochlear bundle acts as a sharp band-pass filter by suppressing the responses outside the focus of attention [8]. It is well established that acoustic stimulation of one cochlea can change afferent responses in the opposite ear, an effect mediated by medial efferent system [9-11].

The outer hair cells are directly innervated and modulated by the medial efferent system. Functioning of the system is generally assessed using contralateral suppression of otoacoustic emissions (OAEs) where there is a reduction in amplitude of the order of 1-4 $\mathrm{dB}$ due to a suppressor stimulus [12]. The contralateral noise reduces the movement of outer hair cells in the ipsilateral ear (because of the inhibition induced by the efferent system) causing reduction in OAE amplitude. Kumar and Barman [10] reported that 
contralateral suppression of the acoustic reflex may also be used as an indicator to check the functioning of the efferent system. Contralateral suppression of the acoustic reflex can be determined by a decrease in the amplitude (or increase in the threshold) of the middle ear muscle reflex by a suppressor stimulus in the contralateral ear.

Contralateral suppression of the acoustic reflex threshold (CSART) or contralateral suppression of the acoustic reflex amplitude (CSARA) is more widely applicable to the clinical population, as the middle ear stapedius reflex can be elicited even when there is moderate or moderately severe sensorineural hearing loss [10]. Hence, it can be used as a powerful diagnostic tool (compared to contralateral OAE suppression) for assessing the efferent auditory pathway. Some studies report that cortical functions (visual or auditory attention tasks) can affect the functioning of the olivocochlear bundles via efferent neural pathways $[13,14]$. The suppression is usually measured in the passive attention condition where the subject is not given any specific task. The experimenter lacks any control over the attention paid by the subject to the stimuli, contralateral noise, or any external stimuli. There have only been a limited number of studies that have assessed the role of visual attention tasks on the medial efferent system [7].

However, there are many studies which report that interactions between sensory systems are essential for the accuracy and completeness of the perception of events [15-18]. The orienting network is focused on the ability to prioritize sensory (e.g., visual and auditory) input by selecting a spatial location (spatial orienting; Petersen \& Posner, [19]) or time event (temporal orienting; see Battelli et al. [20] for a review). Attention orienting is often compared to a spotlight that moves to a specific region in the visual space, or to an event in time, improving information processing in the attended location [21,22]. The orientation that comes from attention improves perception in visual tasks such as contrast sensitivity, texture segmentation, and visual search by intensifying the signal and enhancing spatial resolution, as well as reducing the effect of noise outside the focus of attention [21,23-25]. However, the attention spotlight is not only oriented to a specific location but can also be adjusted in size. Neuroimaging studies suggest that frontal and posterior areas are involved in the orienting of attention. Human and animal studies have shown that frontal eye fields are involved not only in orienting [22] but also in attentional zooming [26].

The literature also reports that a mild deficit in the attention network (including in the magnocellular-dorsal (MD) stream) could underlie some neurodevelopmental disorders. The M-D stream is considered blind to colors and responds optimally to contrast differences, low spatial frequencies, high temporal frequencies, and both real and illusory motion [27-33]. Individuals with developmental dyslexia are less sensitive (than normal reading controls) to luminance patterns and motion displays with high temporal and low spatial frequencies. However, they perform similarly to the controls on tasks preferentially associated with the parvocellular-ventral (P-V) pathway [26]. There are recent studies on children with developmental dyslexia which showed a lower performance in both the tasks that tap M (e.g., the spatial frequency doubling illusion [34]) and D (e.g., rotating tilted lines illusion [35]) portions of the M-D pathway - not only in comparison with agematched controls, but also with reading-level-matched controls [36,37]. It is also interesting to note that children with autism spectrum disorder [38,39] and with specific language impairment [40] also present attention disorders, indicating how attention dysfunction can underlie different developmental outcomes. Recently, Gori et al. [37,41] demonstrated a causal link between magnocellular-dorsal deficit and dyslexia; this study used the rotating tilted lines illusion and the accordion grating illusion previously reported by Gori et al. [28].

Bulkin and Groh [15] reported that visual-auditory interactions provide a perceptual advantage by combining information from two modalities. They also suggested that unimodal brain regions play a predominant role in multisensory processing. Thus, many studies suggest that there are complex interconnections between the visual and auditory neural networks and that these are important for perception of stimuli [15]. Other studies, based on fMRI and ERP, suggest that visual attention tasks activate other sensory cortices as well, including the auditory cortex [16-18]. de Boer and Thornton [7] investigated the top-down effects that different tasks have on contralateral suppression of OAEs. They reported that the recording noise floor was lower for an active auditory attention task compared to the no-task condition, and the suppression was also found to be smaller. In addition, there was no difference between no task and non-auditory tasks. They concluded that this suppression is due to a top-down influence when attention is focused on the test ear. Froehlich et al. [13] also reported that contralateral suppression of OAEs was absent in sleep.

However, there are still no studies reported in literature which assess the suppression of acoustic reflexes by different visual attention tasks. Thus, the present study attempts to determine the changes in the amount of CSART and CSARA when participants were provided with different visual attention tasks. The different tasks were graded in terms of attention, which ranged from absence of visual attention, passive visual attention, and two active visual attention tasks (one with only active visual attention and the other which required active hand-eye co-ordination). If active visual attention enhances suppression, this could be important in terms of appropriately designing and interpreting clinical suppression experiments. The finding could also be useful for enhancing the size of suppression effects, increasing the clinical efficacy of contralateral suppression of acoustic reflexes. Hence, the present study aims to determine whether different levels of visual attention have an effect on medial olivocochlear bundle functioning when assessed through contralateral suppression of acoustic reflexes. The work assesses the effect of four different visual attention tasks (no attention, passive attention, and two active visual attention tasks) on suppression using CSART and CSARA. It also examines whether there are gender effects. 
Table 1. Mean and standard deviation of acoustic reflex threshold (in dB SPL) with and without noise for all four conditions of attention

\begin{tabular}{|c|c|c|c|c|c|c|c|c|c|c|c|c|}
\hline \multirow{3}{*}{$\begin{array}{l}\text { Stimuli } \\
\text { used }\end{array}$} & \multicolumn{4}{|c|}{$500 \mathrm{~Hz}$} & \multicolumn{4}{|c|}{$1000 \mathrm{~Hz}$} & \multicolumn{4}{|c|}{$2000 \mathrm{~Hz}$} \\
\hline & \multicolumn{2}{|c|}{$\begin{array}{l}\text { Acoustic reflex } \\
\text { threshold } \\
\text { without noise } \\
\text { (dB SPL) }\end{array}$} & \multicolumn{2}{|c|}{$\begin{array}{c}\text { Acoustic reflex } \\
\text { threshold with } \\
\text { noise } \\
\text { (dB SPL) }\end{array}$} & \multicolumn{2}{|c|}{$\begin{array}{l}\text { Acoustic reflex } \\
\text { threshold } \\
\text { without noise } \\
\text { (dB SPL) }\end{array}$} & \multicolumn{2}{|c|}{$\begin{array}{c}\text { Acoustic reflex } \\
\text { threshold with } \\
\text { noise } \\
\text { (dB SPL) }\end{array}$} & \multicolumn{2}{|c|}{$\begin{array}{l}\text { Acoustic reflex } \\
\text { threshold } \\
\text { without noise } \\
\text { (dB SPL) }\end{array}$} & \multicolumn{2}{|c|}{$\begin{array}{c}\text { Acoustic reflex } \\
\text { threshold with } \\
\text { noise } \\
\text { (dB SPL) }\end{array}$} \\
\hline & Mean & SD & Mean & SD & Mean & SD & Mean & SD & Mean & SD & Mean & SD \\
\hline No attention & 82.93 & 5.7 & 85.06 & 6.4 & 80.8 & 5.1 & 83.4 & 5.9 & 84.8 & 6.1 & 86.7 & 6.4 \\
\hline Passive attention & 83.8 & 6.1 & 87.16 & 6.4 & 83.09 & 6.05 & 87.1 & 5.83 & 83.8 & 5.83 & 86.5 & 6.05 \\
\hline $\begin{array}{l}\text { Active attention } \\
\text { (spot differences) }\end{array}$ & 83.5 & 5.2 & 89.5 & 5.83 & 80.8 & 5.29 & 86.5 & 5.19 & 83.5 & 6.05 & 88.7 & 5.9 \\
\hline $\begin{array}{l}\text { Active attention } \\
\text { (playing game) }\end{array}$ & 83.07 & 5.83 & 91.75 & 6.15 & 80.77 & 5.89 & 89.22 & 5.12 & 83.4 & 5.8 & 89.64 & 6.8 \\
\hline
\end{tabular}

\section{Material and methods}

\section{Participants}

Exactly 30 individuals (15 males and 15 females) between the age of 17 and 30 years (mean age 19.2; $\mathrm{SD}=3.45$ ) participated in the study. All participants had pure tone thresholds within $15 \mathrm{~dB}$ HL from 250 to $8000 \mathrm{~Hz}$. None of the subjects reported previous history of use of ototoxic drugs, long/short term exposure to high-level noise, or otologi$\mathrm{cal} /$ neurological disease. Informed consent was obtained from all participants. All participants had normal vision, confirmed by an ophthalmologist. All tests were carried out in sound-treated audiometric rooms with permissible noise levels standards of ANSI S3.1-1999 (R 2013).

\section{Procedure}

Pure tone air conduction (AC) and bone conduction (BC) thresholds were estimated using the modified Hughson and Westlake procedure (42). AC thresholds were obtained from 0.25 to $8 \mathrm{kHz}$ and $\mathrm{BC}$ thresholds from 0.25 to $4 \mathrm{kHz}$ at octave frequencies. Speech identification scores were obtained for phonemically balanced words developed for adults in Kannada by Yathiraj and Vijayalakshmi [43]. Recorded word lists were routed from a PC through a 2-channel diagnostic audiometer (Piano Inventis) through TDH 50 headphones at $40 \mathrm{~dB}$ SL (re: SRT).

\section{Baseline measurement}

A GSI-Tympstar (version 2) middle ear analyzer was used to assess middle ear function and suppression. A tympanogram was recorded for all participants prior to measurement of the acoustic reflex. In each individual the acoustic reflex threshold (ART) was determined at $0.5,1$, and $2 \mathrm{kHz}$ in the right ear in $1 \mathrm{~dB}$ steps using a $226 \mathrm{~Hz}$ probe tone. In addition, the reflex amplitude at $10 \mathrm{~dB}$ SL with respect to reflex threshold was noted for all stimuli.

\section{Measurement of CSART and CSARA}

CSART and CSARA were measured under four visual attention conditions. The four conditions used were eyes closed (no visual attention), watching a silent video with captioning (passive visual attention), spotting the differences between two pictures (active visual attention), and playing a visually based game - Pac-man (active visual attention requiring hand-eye co-ordination). Without altering the probe placement, ART and reflex amplitude at 10 dB SL (ref: ART) were established again for all four conditions when white noise in the contralateral ear was present. The threshold for white noise was determined using calibrated Piano Inventis audiometer. Contralateral white noise was presented through an ER-3A insert receiver at $40 \mathrm{~dB}$ SL to the left ear. The acoustic reflex threshold was also determined for broad-band noise (BBN) in the left ear. To ensure that the white noise did not produce an acoustic reflex in the contralateral ear, noise was kept at a level below the acoustic reflex threshold for broad-band noise. The order of presentation of reflex eliciting stimuli and visual attention tasks were randomized.

\section{Statistical analysis}

The results obtained in the study were analyzed statistically using the Statistical Package for Social Sciences (SPSS) Statistics for Windows, Version 20.0, (IBM Corp., Armonk, New York).

\section{Results}

Results showed that there was elevation of ART and reduction in the reflex amplitude with contralateral noise for all the reflex eliciting stimuli under all four attention conditions. The amount of suppression of ART in all the four conditions is shown in Table 1. The amount of reduction in acoustic reflex amplitude under all four conditions is shown in Table 2. A paired sample $t$-test showed that there was a significant difference $(p<0.05)$ with and without noise for all the stimulus conditions in all four visual attention tasks for both CSART and CSARA.

The amount of suppression for CSART and CSARA was calculated for all three frequencies and it was compared across visual conditions. The mean and standard deviation (SD) of CSART for all the conditions is shown in Figure 1. The mean and SD of CSARA for all the conditions is shown in Figure 2. The increase in the mean amount of suppression (ART elevation and reduction of reflex amplitude) 
Table 2. Mean and standard deviation of acoustic reflex amplitude (in $\mathrm{mL}$ ) with and without noise for all the conditions

\begin{tabular}{|c|c|c|c|c|c|c|c|c|c|c|c|c|}
\hline \multirow{3}{*}{$\begin{array}{l}\text { Stimuli } \\
\text { used }\end{array}$} & \multicolumn{4}{|c|}{$500 \mathrm{~Hz}$} & \multicolumn{4}{|c|}{$1000 \mathrm{~Hz}$} & \multicolumn{4}{|c|}{$2000 \mathrm{~Hz}$} \\
\hline & \multicolumn{2}{|c|}{$\begin{array}{l}\text { Acoustic reflex } \\
\text { amplitude } \\
\text { without noise } \\
(\mathrm{mL})\end{array}$} & \multicolumn{2}{|c|}{$\begin{array}{l}\text { Acoustic reflex } \\
\text { amplitude with } \\
\text { noise }(\mathrm{mL})\end{array}$} & \multicolumn{2}{|c|}{$\begin{array}{c}\text { Acoustic reflex } \\
\text { amplitude } \\
\text { without noise } \\
(\mathrm{mL})\end{array}$} & \multicolumn{2}{|c|}{$\begin{array}{l}\text { Acoustic reflex } \\
\text { amplitude with } \\
\text { noise }(\mathrm{mL})\end{array}$} & \multicolumn{2}{|c|}{$\begin{array}{l}\text { Acoustic reflex } \\
\text { amplitude } \\
\text { without noise } \\
(\mathrm{mL})\end{array}$} & \multicolumn{2}{|c|}{$\begin{array}{c}\text { Acoustic reflex } \\
\text { amplitude with } \\
\text { noise }(\mathrm{mL})\end{array}$} \\
\hline & Mean & SD & Mean & SD & Mean & SD & Mean & SD & Mean & SD & Mean & SD \\
\hline No attention & 0.099 & 0.02 & 0.091 & 0.04 & 0.103 & 0.035 & 0.095 & 0.04 & 0.102 & 0.03 & 0.082 & 0.04 \\
\hline Passive attention & 0.083 & 0.03 & 0.075 & 0.02 & 0.096 & 0.03 & 0.086 & 0.02 & 0.089 & 0.02 & 0.073 & 0.02 \\
\hline $\begin{array}{l}\text { Active attention } \\
\text { (spot differences) }\end{array}$ & 0.087 & 0.01 & 0.063 & 0.03 & 0.093 & 0.02 & 0.063 & 0.01 & 0.095 & 0.03 & 0.065 & 0.01 \\
\hline $\begin{array}{l}\text { Active attention } \\
\text { (playing game) }\end{array}$ & 0.093 & 0.02 & 0.055 & 0.01 & 0.085 & 0.035 & 0.053 & 0.02 & 0.102 & 0.025 & 0.064 & 0.03 \\
\hline
\end{tabular}
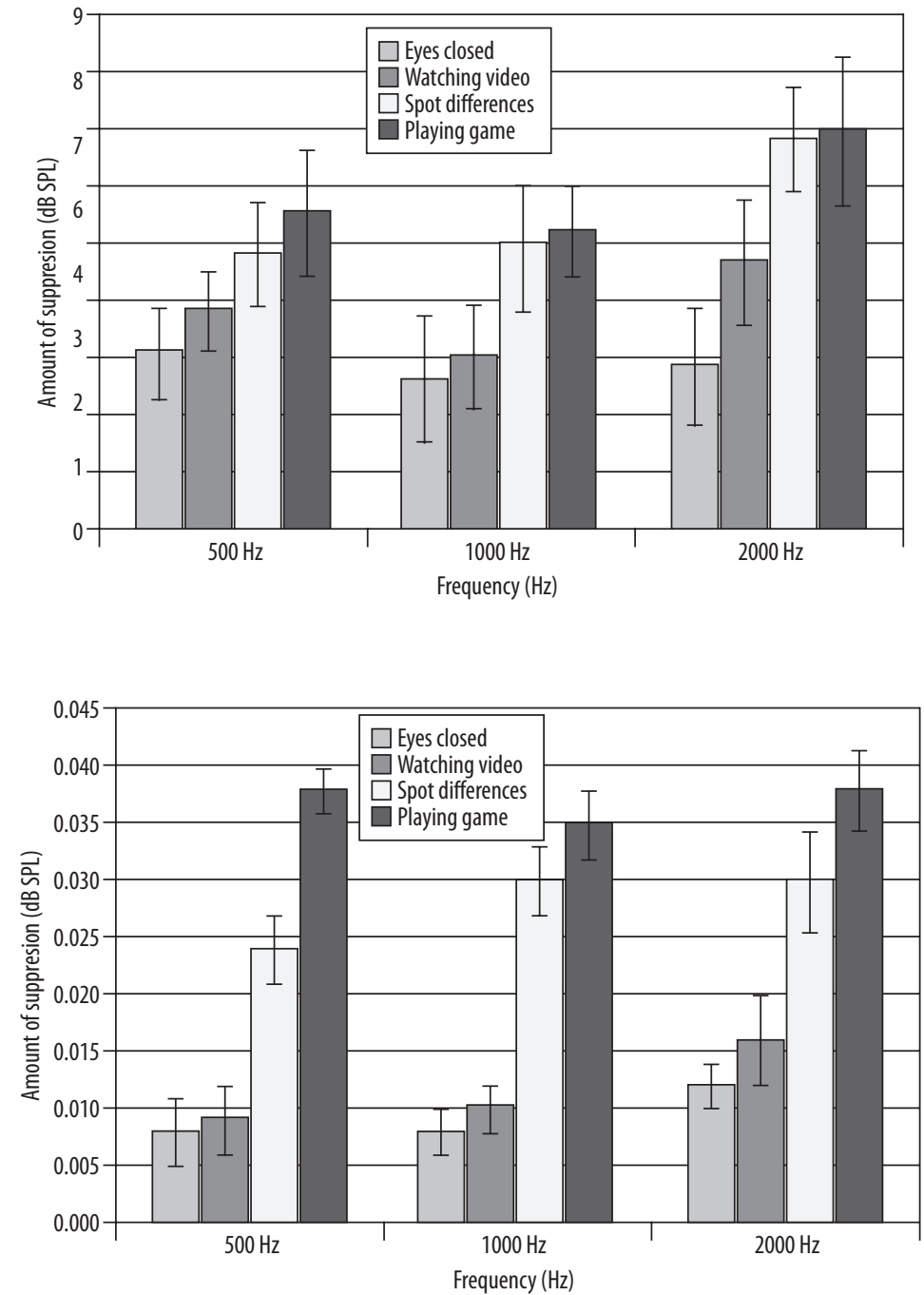

Figure 1. Mean and standard deviation of contralateral suppression of acoustic reflex threshold (CSART) across frequencies for all four visual attention conditions

Figure 2. Mean and standard deviation of contralateral suppression of acoustic reflex amplitude (CSARA) across frequencies for all four visual attention conditions was found to be non-significant in the eyes closed condition, minimal for the 'watch the video' task, and significantly higher for the 'spot the difference' task. The maximum suppression was noticed for the 'play the game' task which required hand-eye co-ordination.
Mixed ANOVAs were done considering suppression (ART and amplitude) as within-subject factors and gender as a between-subject factor. The result showed significant main effect of suppression for ART $[\mathrm{F}(11,319)=8.17, p<0.001]$ and suppression of reflex amplitude $[\mathrm{F}(11,319)=4.798, p<0.001]$ 
across conditions. Bonferroni's multiple group comparison suggested that there was a significant difference $(p<0.05)$ between no attention, passive attention, and both active visual attention tasks for CSART and CSARA. However, there was no significant difference $(p>0.05)$ between the two active visual attention tasks for CSART and CSARA. There was also no significant interaction between gender and suppression of ART $[\mathrm{F}(11,319)=1.28, p>0.05)]$ and suppression of reflex amplitude $[\mathrm{F}(11,319)=1.08, p>0.05)]$. The suppression values for ART and reflex amplitude were not significantly different $(p>0.05)$ across frequencies.

\section{Discussion}

The result of the study shows that visual attention enhances the amount of suppression of acoustic reflexes. The maximum amount of suppression in acoustic reflexes occurred for the active visual attention condition, which required hand-eye co-ordination, and it was minimal for the eyes closed condition. These results strengthen the notion that the efferent system plays a major role in attention $[7,44]$. There is anatomical and physiological evidence which suggests that the efferent system reduces the motion of the basilar membrane [45], and the potential generated by inner hair cells [46], causing suppression of acoustic reflexes. In addition to these phenomena, extra visual attention can enhance the inhibitory effect of the medial efferent system $[7,14]$. There is evidence which suggest that the olivary complex receives input from the auditory cortex, both directly and via the inferior colliculus [47]. All these studies suggest that there is a top-down effect of the auditory cortex on functioning of the medial efferent system. Thus, visual attention can directly affect the efferent system by increasing the amount of suppression, and the strength of the suppression depends on the amount of attention on the visual task.

There are many studies which report the overlap of the visual and auditory systems [15-18]. Vision and audition together are capable of providing fine-grained spatial and temporal information about related objects and events [15]. There are studies in the literature which explain the interaction of the auditory and visual systems in attention tasks [16-18]. Using fMRI and event related potentials, it has been reported that spatial attention to a visual stimulus (which occurs synchronously with a taskirrelevant sound) activates both the visual and auditory cortex simultaneously [16], indicating the spread of attention across space and modality. Zimmer and colleagues also found, using an fMRI study of the anterior cingulated gyrus, interaction of the visual and auditory cortices in visual attention tasks [17]. A related study [18] reported multisensory spread of attention involving the visual and auditory cortex. Similar interactions of visual attention on the auditory cortex are also reported using studies on event related potentials $[16,18]$. In these ways, visual attention can influence the functioning of the efferent auditory system, leading to larger suppression of acoustic reflexes.

The results of the study agree with previous work on OAEs which found that visual attention increases suppression [44]. However, other studies suggest that the reliability of the OAE suppression magnitude is poor [48]. In addition, the evaluation of the medial efferent system using contralateral suppression of OAEs requires normal cochlear function, and cannot be used in individuals with mild to moderate hearing loss. Therefore, to assess function of the efferent system in individuals with hearing impairment, the findings here suggest that, instead of contralateral suppression of OAE, use of contralateral suppression of acoustic reflexes would be advantageous. However, the amount of suppression seen for contralateral suppression of acoustic reflexes is small [10], and there is a need to enhance the effect size to increase the sensitivity of the test. The results of the present study suggest that the use of a controlled active visual task can improve the effect size, and strength of suppression, compared to the no task condition. Hence, the study provides valuable insights into how top-down attention tasks can influence efferent system functioning. The study also provides useful clinical information about the use of an appropriate visual task while using contralateral suppression of acoustic reflexes to assess efferent effects. However, the standard deviation in the results of the study is high, and so the study needs to be replicated on a larger population.

\section{Conclusions}

The results of the study have shown that maximum values of CSART and CSARA were obtained for active visual attention tasks and were smallest for the no visual attention task. The study highlights that visual attention tasks can have a direct effect on the medial efferent system and supports the role of cortical structures in its modulation. To enhance the effect of suppression, the results of the study also encourages the use of a well-controlled active visual attention task over the traditional condition (uncontrolled attention). This is a potentially important finding which complements other studies on the effect of attention on the medial olivocochlear bundle. However, the study does need to be replicated on a larger population in order to confirm the results.

\section{Acknowledgements}

The authors acknowledge all the participants of the study for their co-operation.

\section{References:}

1. Giraud AL, Wable J, Chays A, Collet L, Chéry-Croze S. Influence of contralateral noise on distortion product latency in humans: is the medial olivocochlear efferent system involved? J Acoust Soc Am, 1997; 102(4): 2219-27.

2. Kumar UA, Vanaja CS. Functioning of olivocochlear bundle and speech perception in noise. Ear Hear, 2004; 25(2): 142-6.
3. Reiter ER, Liberman MC. Efferent-mediated protection from acoustic overexposure: relation to slow effects of olivocochlear stimulation. J Neurophysiol, 1995; 73(2): 506-14.

4. Rajan R. Protective functions of the efferent pathways to the mammalian cochlea: a review. In: Salve RJ (ed.). Noise Induced Hearing loss. St Louis: Mosby Yearbook; 1992; 429-44. 
5. Andéol G, Guillaume A, Micheyl C, Savel S, Pellieux L, Moulin A. Auditory efferents facilitate sound localization in noise in humans. J Neurosci, 2011; 31(18): 6759-63.

6. Giard MH, Collet L, Bouchet P, Pernier J. Auditory selective attention in the human cochlea. Brain Res, 1994; 633(1-2): 353-6.

7. de Boer J, Thornton ARD. Neural correlates of perceptual learning in the auditory brainstem: efferent activity predicts and reflects improvement at a speech-in-noise discrimination task. J Neurosci, 2008; 28(19): 4929-37.

8. Scharf B, Magnan J, Collet L, Ulmer E, Chays A. On the role of the olivocochlear bundle in hearing: a case study. Hear Res, 1994; 75(1-2): 11-26.

9. Buño W. Auditory nerve fiber activity influenced by contralateral ear sound stimulation. Exp Neurol, 1978; 59(1): 62-74.

10. Kumar A, Barman A. Effect of efferent-induced changes on acoustical reflex. Int J Audiol, 2002; 41(2): 144-7.

11. Warren EH, Liberman MC. Effects of contralateral sound on auditory-nerve responses. I. Contributions of cochlear efferents. Hear Res, 1989; 37(2): 89-104.

12. Berlin CI, Hood LJ, Wen H, Szabo P, Cecola RP, Rigby P et al. Contralateral suppression of non-linear click-evoked otoacoustic emissions. Hear Res, 1993; 71(1-2): 1-11.

13. Froehlich P, Collet L, Morgon A. Transiently evoked otoacoustic emission amplitudes change with changes of directed attention. Physiol Behav, 1993; 53(4): 679-82.

14. Maison S, Micheyl C, Collet L. Influence of focused auditory attention on cochlear activity in humans. Psychophysiology, 2001; 38(1): 35-40.

15. Bulkin DA, Groh JM. Seeing sounds: visual and auditory interactions in the brain. Curr Opin Neurobiol, 2006; 16(4): 415-9.

16. Busse L, Roberts KC, Crist RE, Weissman DH, Woldorff MG. The spread of attention across modalities and space in a multisensory object. Proc Natl Acad Sci USA, 2005; 102: 18751-6.

17. Zimmer U, Roberts KC, Harshbarger TB, Woldorff MG. Multisensory conflict modulates the spread of visual attention across a multisensory object. Neuroimage, 2010; 52(2): 606-16.

18. Zimmer U, Itthipanyanan S, Grent-'t-Jong T, Woldorff MG. The electrophysiological time course of the interaction of stimulus conflict and the multisensory spread of attention. Eur J Neurosci, 2010; 31(10): 1744-54.

19. Petersen SE, Posner MI. The attention system of the human brain: 20 years after. Annu Rev Neurosci, 2012; 35: 73-89.

20. Battelli L, Pascual Leone A, Cavanagh P. The "when" pathway of the right parietal lobe. Trends Cogn Sci, 2007; 11: 204-10.

21. Carrasco M. Visual attention: the past 25 years. Vision Res, 2011; 51(13): 1484-525.

22. Corbetta M, Shulman GL. Control of goal-directed and stimulus-driven attention in the brain. Nat Rev Neurosci, 2002; 3(3): 201-15.

23. Facoetti A, Molteni M. Is attentional focusing an inhibitory process at distractor location? Cogn Brain Res, 2000; 10(1-2): 185-8.

24. Bellocchi S, Muneaux M, Bastien-Toniazzo M, Ducrot S. I can read it in your eyes: what eye movements tell us about visuoattentional processes in developmental dyslexia. Res Dev Disabil, 2013; 34(1): 452-60.

25. Reynolds JH, Heeger DJ. The normalization model of attention. Neuron, 2009; 61(2): 168-85.

26. Ronconi L, Basso D, Gori S, Facoetti A. TMS on right frontal eye fields induces an inflexible focus of attention. Cereb Cortex, 2014; 24(2): 396-402.
27. Gori S, Giora E, Stubbs DA. Perceptual compromise between apparent and veridical motion indices: the unchained-dots illusion. Perception, 2010; 39(6): 863-6.

28. Gori S, Giora E, Yazdanbakhsh A, Mingolla E. A new motion illusion based on competition between two kinds of motion processing units: the accordion grating. Neural Net, 2011; 24(10): 1082-92.

29. Gori S, Hamburger K, Spillmann L. Reversal of apparent rotation in the enigma-figure with and without motion adaptation and the effect of T-junctions. Vision Res, 2006; 46(19): 3267-73.

30. Gori S, Yazdanbakhsh A. The riddle of the rotating-tilted-lines illusion. Perception, 2008; 37(4): 631-5.

31. Yazdanbakhsh A, Gori S. A new psychophysical estimation of the receptive field size. Neurosci Lett, 2008; 438(2): 246-51.

32. Ruzzoli M, Gori S, Pavan A, Pirulli C, Marzi CA, Miniussi C. The neural basis of the enigma illusion: a transcranial magnetic stimulation study. Neuropsychologia, 2011; 49(13): 3648-55.

33. Gori S, Agrillo C, Dadda M, Bisazza A. Do fish perceive illusory motion? Sci Rep, 2014; 4: 6443

34. Kelly D. Frequency doubling in visual responses. J Opt Soc Am, 1966; 56: 1638-42.

35. Gori S, Hamburger K. A new motion illusion: the rotatingtilted-lines illusion. Perception, 2006; 35(6): 853-7.

36. Gori S, Cecchini P, Bigoni A, Molteni M, Facoetti A. Magnocellular-dorsal pathway and sub-lexical route in developmental dyslexia. Front Hum Neurosci, 2014; 8: 460.

37. Gori S, Seitz AR, Ronconi L, Franceschini S, Facoetti A. Multiple causal links between magnocellular-dorsal pathway deficit and developmental dyslexia. Cereb Cortex, 2015; pii: bhv206 [Epub ahead of print].

38. Ronconi L, Gori S, Giora E, Ruffino M, Molteni M, Facoetti A. Deeper attentional masking by lateral objects in children with autism. Brain Cogn, 2013; 82(2): 213-8.

39. Ronconi L, Gori S, Ruffino M, Molteni M, Facoetti A. Zoomout attentional impairment in children with autism spectrum disorder. Cortex, 2013; 49(4): 1025-33.

40. Dispaldro M, Leonard LB, Corradi N, Ruffino M, Bronte T, Facoetti A. Visual attentional engagement deficits in children with specific language impairment and their role in real-time language processing. Cortex, 2013; 49(8): 2126-39.

41. Gori S, Mascheretti S, Giora E, Ronconi L, Ruffino M, Quadrelli $\mathrm{E}$ et al. The DCDC2 intron 2 deletion impairs illusory motion perception unveiling the selective role of magnocellular-dorsal stream in reading (dis)ability. Cereb Cortex, 2015; 25(6): 1685-95.

42. Carhart R, Jerger JF. Preferred method for clinical determination of pure-tone thresholds. J Speech Hear Disord, 1959; 24: 330-45.

43. Yathiraj A, Vijayalakshmi CS. Phonemically balanced wordlist in Kannada. University of Mysore; 2005

44. Ferber-Viart C, Duclaux R, Collet L, Guyonnard F. Influence of auditory stimulation and visual attention on otoacoustic emissions. Physiol Behav, 1995; 57(6): 1075-9.

45. Mountain DC. Changes in endolymphatic potential and crossed olivocochlear bundle stimulation alter cochlear mechanics. Science, 1980; 210(4465): 71-2.

46. Brown MC, Nuttall AL. Efferent control of cochlear inner hair cell responses in the guinea-pig. J Physiol, 1984; 354: 625-46.

47. Mulders WH, Robertson D. Evidence for direct cortical innervation of medial olivocochlear neurones in rats. Hear Res, 2000; 144(1-2): 65-72.

48. Kumar UA, Methi R, Avinash MC. Test/retest repeatability of effect contralateral acoustic stimulation on the magnitudes of distortion product otoacoustic emissions. Laryngoscope, 2013; 123(2): 463-71. 